\title{
Peran Penyuluh Pertanian Terhadap Peningkatan Wawasan/ Pengetahuan Dalam Meningkatkan Produksi Padi di Desa Tellulimpo Kec. Marioriawa Kab. Soppeng
}

The Role of Agricultural Extension Officers in Increasing Insight/Knowledge in Increasing Rice Production in Tellulimpo Village, Kec. Marioriawa Kab. Soppeng

\author{
Sudarmo $^{1^{*}}$ Irmayani $^{1}$, Yusriadi ${ }^{1}$ \\ *Email: sudarmoomo52@gmail.com \\ ${ }^{1}$ Fakultas Pertanian, Peternakan dan Perikanan Universitas Muhammadiyah Parepare \\ Diterima: 25 September 2021 / Disetujui: 24 Desember 2021
}

\begin{abstract}
ABSTRAK
Penelitian bertujuan untuk mengkaji peran penyuluh pertanian terhadap produksi petani padi di Desa Tellu Limpoe Kecamatan Marioriawa Kabupaten Soppeng. Penelitian ini berlokasi di Desa Tellu Limpoe Kecamatan Marioriawa Kabupaten Soppeng. Teknik pengumpulan data dalam penelitian ini yaitu observasi dan wawancara sedangkan jenis dan sumber data yang digunakan yaitu data primer dan sekunder. Analisa data yang digunakan pada penelitian ini statistik deskriptif dan Skala linker. Hasil penelitian menunjukkan bahwa Persepsi masyarakat terhadap peran penyuluh pertanian terhadap peningkatan wawasan/pengetahuan dalam meningkatkan produksi petani padi adalah indikator 1) Peran penyuluh sebagai pembimbing petani, 2) Peran penyuluh sebagai teknisi lapangan, 3) Peran penyuluh sebagai penghubung antara lembaga dengan petani, dan 4) Peran penyuluh pertanian dalam meningkatkan hasil petani padi, semuanya sangat berperan dalam meningkatkan wawasan/pengetahuan dalam meningkatkan produsi petani padi dan juga peran penyuluh sangat penting bagi petani di Desa Tellulimpoe untuk dapat meningkatka produksi padi.
\end{abstract}

Kata Kunci: Pengaruh Penyuluh, Peningkatan Wawasan, Produksi Padi

\section{ABSTRACT}

The research aims to examine the role of agricultural extension workers in the production of rice farmers in Tellu Limpoe Village, Marioriawa District, Soppeng Regency. This research is located in Tellu Limpoe Village, Marioriawa District, Soppeng Regency. Data collection techniques in this study are observation and interviews while the types and sources of data used are primary and secondary data. Analysis of the data used in this study is descriptive statistics and linker scale. The results showed that the public perception of the role of agricultural extension workers to increase insight / knowledge in increasing the production of rice farmers is an indicator 1) The role of extension workers as farmers' supervisors, 2) The role of extension workers as field technicians, 3) The role of extension workers as a liaison between institutions and farmers, and 4) The role of agricultural instructors in increasing the yield of rice farmers, all of which play an important role in increasing insight / knowledge in increasing the production of rice farmers and also the role of extension workers is very important for farmers in the village of Tellulimpoe to be able to increase rice production.

Keywords: Influence of Instructor, Increased Insight, Production Paddy

(c) $\underset{\mathrm{EY}}{\text { (i) }}$ This work is licensed under Creative Commons Attribution License 4.0 CC-BY International license

\section{A. PENDAHULUAN}

Penyuluh pertanian mempunyai

tugas untuk menguatkan para petani dalam meningkatkan produktivitas padi

secara maksimal. Banyak program yang

telah dibentuk dan diberikan kepada 
petani untuk memotivasi serta mendorong para petani dalam meningkatkan usaha taninya. Salah satu program yang dibentuk oleh Pemerintah mengenai model tanam SRI (Sistem of Rice Intensification) berfungsi untuk meminimalisir biaya-biaya yang dikeluakan oleh para petani dalam usaha tani padi.

Padi merupakan bahan pangan pokok bagi penduduk Indonesia. Selain sebagai sumber pangan pokok juga menjadi sumber penghasilan bagi petani dan untuk memenuhi kebutuhan hidup sehari-hari bagi masyarakat, Seperti pada tahun 2010 , luas panen di sektor pertanian Sulawesi Selatan mencapai hasil produksi padi sebanyak 4.382.443 ton. Ada sebanyak tujuh kabupaten di Sulawesi Selatan sebagai penghasil produksi padi terbesar, dan salah satunya adalah Kabupaten Soppeng dengan kontribusi produksi padi sebesar 252.565 ton. Sektor pertanian menjadi pendorong utama perekonomian di Kabupaten Soppeng dan termasuk salah satu daerah penghasil padi/beras di Provinsi Sulawesi Selatan.

Kabupaten Soppeng merupakan salah satu kabupaten yang terdapat di Provinsi Sulawesi Selatan yang memiliki beberapa potensi di bidang pertanian, pertambangan, perkebunan, jasa dan pariwisata. Kabupaten Soppeng memiliki wilayah yang subur sehingga memiliki keunggulan dalam hal pertanian dan hampir semua jenis tanaman baik pangan, palawija, sayuran, buah-buahan dan perkebunan terdapat di Soppeng.

Tabel 1. Luas Panen dan Hasil Produksi Padi Se-Provinsi Sulawesi Selatan Tahun 2017

\begin{tabular}{lcc}
\hline \multicolumn{1}{c}{ Kabupaten / } & \multicolumn{2}{c}{ Padi } \\
Kota & $\begin{array}{c}\text { Luas Panen } \\
\text { ( ha })\end{array}$ & $\begin{array}{c}\text { Produksi ( } \\
\text { ton ) }\end{array}$ \\
\hline Kab. Bone & 149.656 & 763.000 \\
Kab. Pinrang & 94.281 & 542.109 \\
Kab. Wajo & 131.459 & 699.111 \\
Kab. Sidrap & 82.875 & 474.179 \\
Kab. Gowa & 61.139 & 309.909 \\
Kab. Luwu & 65.954 & 329.249 \\
Kab. Soppeng & $\mathbf{5 0 . 3 5 9}$ & $\mathbf{2 9 5 . 3 2 6}$ \\
Kab. Maros & 47.684 & 248.919 \\
Kab. Bulukumba & 40.845 & 218.480 \\
Kab. Luwu Utara & 41.742 & 214.307 \\
\hline
\end{tabular}

Dalam kurun 2 tahun terakhir, produksi padi di Kabupaten Soppeng mengalami naik turun. Dan pada tahun 2016 jumlah produksi padi sebanyak 267.188 ton dengan produktivitas 6,480 ton/ha, jika dibandingkan dengan tahun 2015 terjadi penurunan dengan jumlah produksi 281.692 ton, atau menurun sekitar 5,15\%.

Peran penyuluh pertanian memiliki peranan yang sangat penting dalam peningkatan produksi pertanian di indonesia. Pelaksanaan penyuluhan pertanian sejak dulu mengalami naik turun sesuai dengan perkembangan zaman 
dan berperan penting dalam membangun pertanian yang merupakan bagian dari pembangunan nasional. Indonesia pernah menjadi swasembada pangan khusus beras, dan bahkan pernah mengekspor beras ke luar negeri. Dalam hal ini menjadi pembuktian bahwa pertanian Indonesia telah melalui proses dari pertanian tradisional menjadi pertanian yang mampu memanfaatkan sumber daya secara optimal. Penyuluh pada dasarnya dapat berperan sebagai penyebar hasilhasil penelitian, pelatih pengambilan keputusan, rekan pemberi semangat, pendorong peningkatan produksi, dan pelayan Pemerintah.

Hal inilah yang perlu diadakan pengkajian dan penelitian lebih lanjut. Maka peneli tertarik untuk meneliti tentang "Peran Penyuluh Pertanian terhadap Produksi Petani Padi di Desa Tellu Limpoe Kecamatan Mario Riawa Kabupaten Soppeng”. Adapun tujuan penelitian ini yaitu untuk mengkaji seberapa penting peran penyuluh pertanian terhadap peningkatan produksi petani di Desa Tellulimpoe, Kecamatan Marioriawa, Kabupaten Soppeng.

\section{B. METODE PENELITIAN}

Penelitan ini dilaksanakan pada bulan April sampai Mei 2020 yang berlokasi di Desa Tellulimpoe Kecamatan
Marioriawa Kabupaten Soppeng. Alasan peneliti memilih lokasi ini karena Desa Tellulimpoe merupakan desa yang berpotensial untuk kegiatan produksi pertanian sehingga peneliti tertarik untuk mengetahui seberapa besar peran penyuluh penyuluh pertanian di Desa tersebut dalam meningkatkan produktivitas padi.

\section{Populasi dan Sampel}

Populasi dalam penelitian ini adalah semua petani Padi di Desa Tellu Limpoe Kecamatan Marioriawa Kabupaten Soppeng berjumlah 507 orang petani padi. Dalam penelitian ini digunakan teknik pengembilan sampel secara random dikarena jumlah populasi petani Padi yang cukup besar. Dari jumlah populasi tersebut dilakukan penentuan jumlah sampel yang dapat mewakili populasi. Adapun penentuan jumlah sampel dilakukan dengan menggunakan rumus Slovin dalam Putra Wicaksono (2012) sebagai berikut :

$$
\mathrm{n}=\frac{N}{1+N(e)^{2}}
$$

Keterangan :

$\mathrm{n}=$ Jumlah Sampel

$\mathrm{N}=$ Jumlah Populasi

$\mathrm{E}=$ Tingkat Kelonggaran $(15 \%)$

$$
\text { Tingkat kelonggaran }
$$

$15 \%$ digunakan dengan dasar jumlah tidak lebih dari 2000 populasi menurut Sugiono dalam Rahmayani Sila (2013). 
Sehingga di dapatkan hasil sebagai berikut:

$$
\begin{gathered}
\mathrm{n}=\frac{N}{1+N(15)^{2}} \\
\mathrm{n}=\frac{507}{1+507(0,15)^{2}}=40,86=41
\end{gathered}
$$

Jadi petani dalam penelitian ini yaitu sebanyak 41 orang. Yang terdiri dari 1 penyuluh pertanian dan 40 petani padi.

\section{Teknik Pengumpulan Data}

Teknik pengumpulan data yang digunakan pada penelitian ini yaitu

a. Observasi, yaitu pengumpulan data melalui pengamatan secara langsung terhadap kondisi lokasi penelitian dan masyarakat yang berada di Desa Tellu Limpoe, Kecamatan Marioriawa, Kabupaten Soppeng.

b. Wawancara, yaitu pengumpulan data melalui wawancara langsung dengan petani di Desa Tellu Limpoe, Kecamatan Marioriawa, Kabupaten Soppeng.

\section{Analisis Data}

Analisa data yang digunakan pada penelitian ini yaitu statistik deskriptif dengan menggunakan pengelompokan, penyederhanaan, serta penyajian data seperti tabel distribusi frekuensi dan pengukuran dengan menggunakan skala linker.
Skala linker digunakan untuk menganalisis peran penyuluh pertanian dalam meningkatkan produksi petani padi. Skala linker digunakan untuk menentukan lokasi kedudukan seseorang dalam suatu sikap, mulai dari sangat negatf sampai sangat positif. Penentuan lokasi digunakan dengan mengkuantifikasi respon seseorang terhadap butir pernyataan atau pertanyaan yang disediakan. Variabel yang diukur dengan Skala linkert dijabarkan menjadi Indikator Variabel. Indikator tersebut dijadikan sebagai titik tolak menyusun butir-butir instrumen yang berupa pernyataan atau pertanyaan yang perlu dijawab oleh responden (Adi Yanto 2017). Setiap jawaban dihubungkan dengan bentuk pernyataan atau dukungan persepsi yang diungkapkan dengan katakata yang dikategorikan sebagai berikut :

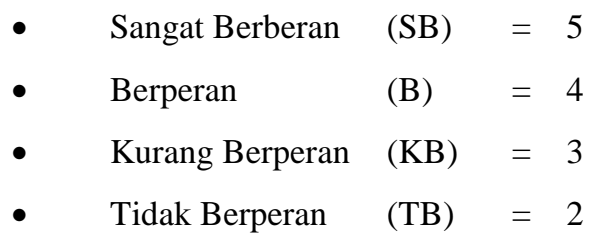

- $\quad$ Tidak Berperan sama sekali (TBSS) $=1$

Untuk pengukuran setiap Indikator penelitian dapat dikemukakan sebagai berikut

a. Indikator Peran Peyuluh Sebagai Pembimbing Petani

Untuk mengukur Indikator Peran Penyuluh sebagai Pembimbing Petani 
dengan menggunakan asumsi dasar interval kelas dan rentang kelas sebagai berikut :

Nilai Maksimal : Skor tertinggi x Jumlah Smpel x Jumlah Pertanyaan

$$
\begin{aligned}
& =5 \times 41 \times 4 \\
& =820
\end{aligned}
$$

Nilai Minimal : Skor terendah x Jumlah

Sampel x Jumlah pertanyaan

$$
\begin{gathered}
=1 \times 41 \times 4 \\
=164 \\
\text { Rentang kelas } \\
=\frac{\text { nilai }}{\text { maksimal }- \text { nilai minimal }} \\
=\frac{820-164}{5}=131
\end{gathered}
$$

Nilai ini dapat di buat kategori

sebagai berikut:

Sangat Berperan $(\mathrm{SP})=688,8-820$

Berperan

(B) $=557,6-688,8$

Kurang Berperan $(\mathrm{KB})=426,4-557,6$

Tidak Berperan $(B)=295,2-426,4$

Tidak Berperan Sama Sekali $($ TBBS $)=164-$ 295,2

b. Indikator Peran Peyuluh Sebagai

Teknisi Lapangan

Untuk mengukur Indikator Peran Penyuluh sebagai teknisi lapangan dengan menggunakan asumsi dasar interval kelas dan rentang kelas sebagai berikut :

Nilai Maksimal : Skor tertinggi x Jumlah Smpel x Jumlah Pertanyaan

$$
\begin{aligned}
& =5 \times 41 \times 4 \\
& =820
\end{aligned}
$$

Nilai Minimal : Skor terendah x Jumlah Sampel x Jumlah pertanyaan

$$
\begin{gathered}
=1 \times 414 \\
=164 \\
\quad \text { Rentang kelas } \\
=\frac{\text { nilai }}{\text { maksimal }- \text { nilai minimal }} \\
=\frac{820-164}{5}=131
\end{gathered}
$$

Nilai ini dapat di buat kategori sebagai berikut:

Sangat Berperan $(\mathrm{SB})=688,8-820$

Berperan $\quad(\mathrm{B})=557,6-688,8$

Kurang Berperan $(\mathrm{KB})=426,4-557,6$

Tidak Berperan $\quad(B)=295,2-426,4$

Tidak Berperan Sama Sekali $($ TBBS $)=164-$

295,2

c. Penyuluh berperan sebagai penghubung antara lembaga penelitian dengan petani:

Untuk mengukur Indikator Penyuluh berperan sebagai penghubung antara lembaga penelitian deengan petanidengan menggunakan asumsi dasar interval kelas dan rentang kelas sebagai berikut :

Nilai Maksimal : Skor tertinggi x Jumlah Smpel x Jumlah Pertanyaan

$$
\begin{aligned}
& =5 \times 41 \times 4 \\
& =820
\end{aligned}
$$

Nilai Minimal : Skor terendah x Jumlah Sampel x Jumlah pertanyaan

$$
\begin{aligned}
& =1 \times 41 \times 4 \\
& =164
\end{aligned}
$$

Rentang kelas

$$
\begin{gathered}
=\frac{\text { nilai maksimal }- \text { nilai minimal }}{\text { jumlah } \text { skor }} \\
=\frac{820-164}{5}=131
\end{gathered}
$$

Nilai ini dapat di buat kategori sebagai berikut: 
Sangat Berperan (SB) $=688,8-820$

Berperan

(B) $=557,6-688,8$

Kurang Berperan $(\mathrm{KB})=426,4-557,6$

Tidak Berperan $(B)=295,2-426,4$

Tidak Berperan Sama Sekali $($ TBBS $)=164-$

295,2

d. Indikator Peran Penyuluh Pertanian dalam meningkatkan Hasil Petani Padi

Untuk mengukur Indikator Peran Penyuluh Pertanian dalam meningkatkan Hasil Petani Padidengan menggunakan asumsi dasar interval kelas dan rentang kelas sebagai berikut :

Nilai Maksimal : Skor tertinggi x Jumlah Smpel x Jumlah Pertanyaan

$$
\begin{aligned}
& =5 \times 41 \times 4 \\
& =820
\end{aligned}
$$

Nilai Minimal : Skor terendah x Jumlah

Sampel x Jumlah pertanyaan

$$
\begin{aligned}
& =1 \times 414 \\
& =164
\end{aligned}
$$

Rentang kelas

$$
\begin{aligned}
& =\frac{\text { nilai maksimal }- \text { nilai minimal }}{\text { jumlah skor }} \\
& =\frac{820-164}{5}=131
\end{aligned}
$$

Nilai ini dapat di buat kategori sebagai berikut:

Sangat Berperan $(\mathrm{SB})=688,8-820$

Berperan $\quad$ (B) $=557,6-688,8$

Kurang Berperan $(\mathrm{KB})=426,4-557,6$

Tidak Berperan $\quad(B) \quad=295,2-426,4$

Tidak Berperan Sama Sekali $($ TBBS $)=164-$

295,2
Untuk pengukuran Indikator secara keseluruhan penelitian dapat dikemukakan sebagai berikut :

Nilai Maksimal : Skor tertinggi x Jumlah Smpel x Jumlah Pertanyaan

$$
\begin{aligned}
& =5 \times 41 \times 6 \\
& =3.280
\end{aligned}
$$

Nilai Minimal : Skor terendah x Jumlah Sampel x Jumlah pertanyaan

$$
\begin{aligned}
& =1 \times 41 \times 16 \\
& =656
\end{aligned}
$$

Rentang kelas

$=\frac{\text { nilai maksimal }- \text { nilai minimal }}{\text { jumlah skor }}$

$$
=\frac{3.280-656}{5}=525
$$

Dari nilai ini dapat di buat kategori sebagai berikut:

Sangat Berperan $(\mathrm{SP}) \quad=2.756-3.281$

Berperan $\quad(B) \quad=2.231-2.756$

Kurang Berperan(KB) $=1.706-2.231$

Tidak Berperan $(\mathrm{B}) \quad=1.181-1.706$

Tidak Berperan Sama Sekali $(\mathrm{TBBS})=656-$ 1.181

\section{HASIL DAN PEMBAHASAN}

Pandangan masyarakat yaitu suatu penilaian seseorang terhadap seseorang tersebut berupa tanggapan yang diberi oleh masyarakat mengenai Peranan Penyuluh pertanian terhadap peningkatan produksi,dimana Penyuluh pertanian yang ada di Kabupaten Soppeng.

Hasil penelitian tentang persepsi masyarakat terhadap peranan penyuluh 
pertanian dapat dilihat pada tabel 2 sebagai berikut.

Tabel 2. Data Hasil Kuisioner Indikator Peran Penyuluh Sebagai Pembimbing Petani

\begin{tabular}{|c|c|c|}
\hline No & Indikator & Jumlah \\
\hline 1. & $\begin{array}{l}\text { Penyuluh membimbing petani } \\
\text { dalam mengatasi hambatan } \\
\text { ataupun permasalahan yang } \\
\text { berasal dari petani misalnya } \\
\text { masalah mengenai pembagian } \\
\text { pengairan }\end{array}$ & 191 \\
\hline 2. & $\begin{array}{l}\text { Penyuluh membimbing petani } \\
\text { dalam menyediakan saprodi } \\
\text { misalnya Traktor, alat semprot } \\
\text { dll }\end{array}$ & 176 \\
\hline 3. & $\begin{array}{l}\text { Penyuluh membimbing petani } \\
\text { dalam hal memberikan solusi } \\
\text { mengenai tata cara pembuatan } \\
\text { pupuk cair, organik maupun } \\
\text { padat }\end{array}$ & 189 \\
\hline 4. & $\begin{array}{l}\text { Penyuluh membimbing petani } \\
\text { dalam mengambil keputusan } \\
\text { misalnya mengenai pertanian } \\
\text { organik }\end{array}$ & 185 \\
\hline & Jumlah & 741 \\
\hline
\end{tabular}

Tabel 2 dapat dijelaskan bahwa terdapat 4 Indikator dengan lima kategori yaitu sangat berperan,berperan,kurang berperan,tidak berperan,tidak berperan sama sekali. Berdasarkan hasil penjumlahan dari indikator pertama yaitu Penyuluh membimbing petani dalam mengatasi hambatan ataupun permasalahan yang berasal dari petani misalnya masalah mengenai pembagian pengairan maka diperoleh bobot dari lima kategori tersebut. Pada kategori sangat berperan maka dapat diperoleh poin $5 \mathrm{x}$ 27 orang yang memilih jadi bobot yang dihasilkan yaitu 135,kategori berperan dapat di peroleh dari $4 \times 14$ jumlah orang yang memilih jdi bobot yang dihasilkan yaitu 56, kategori kurang berperan 0,kategori tidak perperan 0 dan kategori tidak berperan sama sekali diperoleh bobot 0 . Sehingga jumlah bobot yang dihasilkan dari kelima kategori tersebut adalah 191.

Indikator kedua yaitu Penyuluh membimbing petani dalam menyediakan saprodi misalnya Traktor, alat semprot dll maka bobot yang diperoleh dari kategori sangat berperan yaitu 60, kategori berperan 116,kategori kurang berperan 0,kategori tidak berperan dan kategori tidak berperan sama sekali 0. Sehingga jumlah bobot yang dihasilkan dari kelima 176.

Indikator ketiga yaitu Penyuluh membimbing petani dalam hal memberikan solusi mengenai tata cara pembuatan pupuk cair, organik maupun padat maka diperoleh bobot dari kategori sangat berperan yaitu 125,kategori berperan 64,kategori kurang berperan 0,kategori tidak berperan 0 dan kategori tidak berperan sama sekali 0 . Sehingga jumlah bobot yang diperoleh dari kelima kategori tersebut yaitu 189. Sedangkan untuk indicator keempat yaitu Penyuluh membimbing petani dalam mengambil keputusan misalnya mengenai pertanian organik maka bobot yang diperoleh dari 
kategori sangat berperan yaitu 105,kategori berperan 80,kategori kurang berperan 0 ,kategori tidak berperan 0 dan kategori tidak berperan sama sekali 0 . Sehingga jumlah bobot yang dihasilkan dari kelima kategori tersebut adalah 185 .

Pada penelitian Sekar Intem M, dkk (2017) dengan judul penelitian "Peranan Penyuluh Pertanian Dalam Peningkatan Pendapatan Petani Komoditas Padi Di Kecamatan Tanjung Selor Kabupaten Bulungan Kalimantan Utara" yang menyatakan bahwa peranan penyuluh dalam hal ini sangat penting untuk bisa mengubah perilaku petani menuju pertanian yang berwawasan agribisnis. Sebanyak 13,33\% responden menyatakan bahwa penyuluh sebagai pembimbing petani kurang berperan, 36,67 responden yang menyatakan penyuluh sebagai pembimbing petani berperan dan 50\% responden yang menyatakan penyuluh sebagai pembimbing sangat berperan dalam mengembangkan produktivitas petani dalam usahataninya. Sesuai dengan tugas pokok penyuluh maka penyuluh harus mampu berperan untuk mengubah perilaku (pengetahuan, sikap dan keterampilan) petani agar lebih baik lagi dalam usaha taninya. Penyelenggaraan penyuluh pertanian akan berjalan dengan baik apabila ada persamaan persepsi antara penyuluh dan petani serta pihakpihak yang berkepentingan.

Tabel 3. Data Hasil Kuisioner Indikator Peran Penyuluh Sebagai Teknisi Lapangan

\begin{tabular}{|c|c|c|}
\hline No. & Indikator & Jumlah \\
\hline 1. & $\begin{array}{l}\text { Mempengaruhi pencemaran Peny } \\
\text { uluh memiliki keterampilan teknis } \\
\text { yang baik dalam hal pembasmian } \\
\text { hama menggunakan pestisida } \\
\text { nabati }\end{array}$ & 197 \\
\hline 2. & $\begin{array}{l}\text { Penyuluh berperan dalam } \\
\text { memperaktikkan apa yang telah di } \\
\text { demonstrasikan mengenai } \\
\text { program-program penyuluhan }\end{array}$ & 191 \\
\hline 3. & $\begin{array}{l}\text { Penyuluh berperan dalam } \\
\text { memberikan pelayanan yang baik } \\
\text { seperti melayani pengaduan atas } \\
\text { masalah petani seperti banyaknya } \\
\text { serangan hama atau hal lainnya } \\
\text { dengan cepat dan konsisten. }\end{array}$ & 195 \\
\hline 4. & $\begin{array}{l}\text { Penyuluh memberikan } \\
\text { penyuluhan dengan baik disertai } \\
\text { dengan memberikan percontohan }\end{array}$ & 181 \\
\hline & Jumlah & 764 \\
\hline
\end{tabular}

Sumber : Data Primer setelah di Olah, 2019

Dari Tabel 3 dapat dijelaskan bahwa terdapat 4 Indikator dengan lima kategori yaitu sangat berperan,berperan,kurang berperan,tidak berperan,tidak berperan sama sekali. Berdasarkan hasil penjumlahan dari indicator pertama yaitu Mempengaruhi pencemaran Penyuluh memiliki keterampilan teknis yang baik dalam hal pembasmian hama menggunakan pestisida nabati maka diperoleh bobot dari lima kategori tersebut. Pada kategori sangat berperan diperoleh bobot 165,kategori berperan 32,kategori kurang berperan 0,kategori tidak perperan 0 dan kategori tidak berperan sama sekali diperoleh bobot 0 . 
Sehingga jumlah bobot yang dihasilkan dari kelima kategori tersebut adalah 197 .

Indikator kedua yaitu Penyuluh berperan dalam memperaktikkan apa yang telah di demonstrasikan mengenai program-program penyuluhan maka bobot yang diperoleh dari kategori sangat berperan yaitu 140,kategori berperan 48,kategori kurang berperan 3,kategori tidak berperan dan kategori tidak berperan sama sekali 0. Sehingga jumlah bobot yang dihasilkan dari kelima 191 .

Indikator ketiga yaitu Penyuluh berperan dalam memberikan pelayanan yang baik seperti melayani pengaduan atas masalah petani seperti banyaknya serangan hama atau hal lainnya dengan cepat dan konsisten maka diperoleh bobot dari kategori sangat berperan yaitu 155,kategori berperan 40,kategori kurang berperan 0 ,kategori tidak berperan 0 dan kategori tidak berperan sama sekali 0 . Sehingga jumlah bobot yang diperoleh dari kelima kategori tersebut yaitu 195 . Sedangkan untuk indicator keempat yaitu Penyuluh memberikan penyuluhan dengan baik disertai dengan memberikan percontohan maka bobot yang diperoleh dari kategori sangat berperan yaitu 125,kategori berperan 56,kategori kurang berperan 0 ,kategori tidak berperan 0 dan kategori tidak berperan sama sekali 0 .
Sehingga jumlah bobot yang dihasilkan dari kelima kategori tersebut adalah 181 .

Hal ini sejalan dengan hasil penelitian Sundari, Dkk (2015), dengan judul penelitian "Peran Penyuluh Pertanian Terhadap Peningkatan Produksi Usahatani Di Kabupaten Pontianak" mengemukakan bahwa Peranan penyuluh pertanian sebagai teknisi di Kecamatan Sungai Pinyuh dan Kecamatan Anjongan mempunyai hubungan terhadap peningkatan produksi padi di Kabupaten Pontianak. Berdasarkan hasil analisa kendall's tau dapat diketahui bahwa hubungan peranan penyuluhan sebagai teknisi terhadap produksi baik pada Kecamatan Sungai Pinyuh dan Kecamatan Anjongan berpengaruh dimana penyuluh telah menerapkan kepada petani penanaman varietas padi unggul bersertifikat, penggunaan pupuk sesuai rekomendasi setempat serta menerapkan pengolahan tanah menggunakan alat mekanisasi pada usahatani dan sebagainya. Berdasarkan hasil nilai correlation coefficient diketahui bahwa hub ungan korelasi pada Kecamatan Sungai Pinyuh memiliki pengaruh sangat kuat $(0,800-1,000)$, sedangkan pada Kecamatan Anjongan memiliki pengaruh sedang $(0,400-$ 0,599). Perbedaan hubungan korelasi ini 
diduga dari tingkat pendidikan Kecamatan

Sungai Pinyuh yang lebih rendah dibandingkan dengan Kecamatan Anjongan.

Tabel 4. Data Hasil Kuisioner Indikator Peran Penyuluh Sebagai Penghubung Antara Lembaga Penelitian Dengan Petani

\begin{tabular}{clc}
\hline No. & \multicolumn{1}{c}{ Indikator } & Jumlah \\
\hline 1. & $\begin{array}{l}\text { Penyuluh menyampaikan } \\
\text { temuan hasil penelitian } \\
\text { kepada petani }\end{array}$ & 179 \\
2. & $\begin{array}{l}\text { Penyuluh } \\
\text { informasi } \\
\text { penelitian } \\
\text { Penyuluh memberikan saran } \\
\text { saran yang baik mengenai } \\
\text { usaha tani yang lebih } \\
\text { menguntungkan atas dasar } \\
\text { penelitian }\end{array}$ & \\
Penyuluh menjembatani \\
petani dengan lembaga \\
penelitian \\
tanaman mengenai \\
dikembangkan oleh peneliti \\
sebagai tanaman yang \\
unggul
\end{tabular}

Dari Tabel 4 dapat dijelaskan bahwa terdapat 4 Indikator dengan lima kategori yaitu sangat berperan,berperan,kurang berperan,tidak berperan,tidak berperan sama sekali. Berdasarkan hasil penjumlahan dari indicator pertama yaitu Penyuluh menyampaikan temuan hasil penelitian kepada petani maka diperoleh bobot dari lima kategori tersebut. Pada kategori sangat berperan diperoleh bobot 80 kategori berperan 96 kategori kurang berperan 3, kategori tidak perperan 0 dan kategori tidak berperan sama sekali diperoleh bobot 0 . Sehingga jumlah bobot yang dihasilkan dari kelima kategori tersebut adalah 179 .

Indikator kedua yaitu Penyuluh memberikan informasi mngenai penelitian maka bobot yang diperoleh dari kategori sangat berperan yaitu 65 kategori berperan 104, kategori kurang berperan 6, kategori tidak berperan dan kategori tidak berperan sama sekali 0 . Sehingga jumlah bobot yang dihasilkan dari kelima 175 .

Indikator ketiga yaitu Penyuluh memberikan saran saran yang baik mengenai usaha tani yang lebih menguntungkan atas dasar penelitian maka diperoleh bobot dari kategori sangat berperan yaitu 90, kategori berperan 88 , kategori kurang berperan 3,kategori tidak berperan 0 dan kategori tidak berperan sama sekali 0. Sehingga jumlah bobot yang diperoleh dari kelima kategori tersebut yaitu 181. Sedangkan untuk indicator keempat yaitu Penyuluh menjembatani petani dengan lembaga penelitian mengenai tanaman yang dikembangkan oleh peneliti sebagai tanaman yang unggul maka bobot yang diperoleh dari kategori sangat berperan yaitu 90, kategori berperan 88, kategori kurang berperan 3, kategori tidak berperan 0 dan kategori tidak berperan sama sekali 0 . Sehingga jumlah bobot 
yang dihasilkan dari kelima kategori tersebut adalah 181.

$\mathrm{Hal}$ ini juga sejalan dengan penelitian $\mathrm{Ni}$ Komang Maya Gitasmara, dkk pada tahun 2017, menyatakan bahwa peranan PPL dalam pembuatan pupuk organik padat sebagai komunikator diperoleh kategori sangat baik dengan pencapaian skor $85,9 \%$. Pencapaian skor tertinggi adalah bahasa yang digunakan saat kegiatan penyuluhan mencapai kategori sangat baik dengan pencapaian skor 91,0\%. Hasil wawancara yang sudah dilaksanakan, pencapaian skor yang diperoleh pada bahasa yang digunakan, PPL menggunakan bahasa daerah setempat yaitu bahasa daerah (Bali) sehingga informasi yang disampaikan mudah dimengerti petani. Alat bantu yang digunakan penyuluh pada kelompok ternak Putra Kertha Santhi adalah audio visual seperti microphonealat tulis seperti papan tulis, spidol, alat peraga seperti leaflet. Alat bantu tersebut digunakan penyuluh untuk penyuluhan pembuatan pupuk organik padat sehingga petani lebih mudah memahami materi penyuluhan.

Tabel 5. Data Hasil Kuisioner Indikator Peran Penyuluh Pertanian Dalam Meningkatkan Hasil Petani Padi

\begin{tabular}{clc}
\hline No. & \multicolumn{1}{c}{ Indikator } & Jumlah \\
\hline 1. & $\begin{array}{l}\text { Kehadiran penyuluh dalam } \\
\text { pertemuan kelompok tani }\end{array}$ & 186 \\
2. & $\begin{array}{l}\text { Menyediakan sarana } \\
\text { produksi pertanian }\end{array}$ & 176
\end{tabular}

\begin{tabular}{llc} 
3. & $\begin{array}{l}\text { Penyuluh membantu petani } \\
\text { mendapatkan modal }\end{array}$ & 170 \\
$\begin{array}{l}\text { Penyuluh membantu petani } \\
\text { mendapatkan akses dengan } \\
\text { Dinas pertanian }\end{array}$ & 174 \\
Jumlah & $\mathbf{7 0 6}$ \\
\hline Sumber : Data Primer setelah di Olah, 2019.
\end{tabular}

Dari Tabel 5 dapat dijelaskan bahwa terdapat 4 Indikator dengan lima kategori yaitu sangat berperan,berperan,kurang berperan,tidak berperan,tidak berperan sama sekali. Berdasarkan hasil penjumlahan dari indicator pertama yaitu Kehadiran penyuluh dalam pertemuan kelompok tani maka diperoleh bobot dari lima kategori tersebut. Pada kategori sangat berperan diperoleh bobot 115 kategori berperan 68, kategori kurang berperan 3 ,kategori tidak perperan 0 dan kategori tidak berperan sama sekali diperoleh bobot 0 . Sehingga jumlah bobot yang dihasilkan dari kelima kategori tersebut adalah 186.

Indikator kedua yaitu Menyediakan sarana produksi pertanian maka bobot yang diperoleh dari kategori sangat berperan yaitu 70, kategori berperan 100, kategori kurang berperan 6, kategori tidak berperan 0 dan kategori tidak berperan sama sekali 0. Sehingga jumlah bobot yang dihasilkan dari kelima 176.

Indikator ketiga yaitu Penyuluh membantu petani mendapatkan modal maka diperoleh bobot dari kategori sangat berperan yaitu 50, kategori berperan 108 , 
kategori kurang berperan 12, kategori tidak berperan 0 dan kategori tidak berperan sama sekali 0. Sehingga jumlah bobot yang diperoleh dari kelima kategori tersebut yaitu 170. Sedangkan untuk indicator Penyuluh membantu petani mendapatkan akses dengan Dinas pertanian maka bobot yang diperoleh dari kategori sangat berperan yaitu 55, kategori berperan 116, kategori kurang berperan 3, kategori tidak berperan 0 dan kategori tidak berperan sama sekali 0 . Sehingga jumlah bobot yang dihasilkan dari kelima kategori tersebut adalah 174.

Hal ini juga sejalan dengan penelitian Lusiana, dkk pada tahun 2018 yang menyatakan bahwa penyuluh sebagai fasilitator dalam hal ini menyangkut pemanfaatan modal atau bantuan bagi petani. Petani responden yang menjawab pemanfaatan modal/ bantuan sangat baik dan baik adalaah petani yang merasakan bantuan dari penyuluh yang didapatkan melalui kelompok tani. Bantuan tersebut berupa benih, obat-obatan dan kemudahan dalam pengambilan pupuk yang pembayarannya bisa dilunasi setelah panen. Bardasarkan hasil analisis Chi Square diperoleh nilai $x_{\text {hitung }}^{2}(12,17)$ lebih besar jika dibandingkan dengan nilai $x_{\text {tabel }}^{2}(5,99)$ pada taraf nyata $(\alpha) 0,005$, dimana peran penyuluh pertanian sebagai fasilitator petani terhadap peningkatan pendapatan bepengaruh. Jadi, Ho ditolak $H_{1}$ diterima teruji kebenarannya bahwa peran penyuluh pertanian sebagai fasilitator terhadap pendapatan petani padi sawah menunjukkan adanya hubungan yang signifikan. Penilaian para responden terhadap peran penyuluh sebagai fasilitator sejauh ini sudah berperan. Para responden ini menilainya dari penyuluh adanya bantuan modal yang diberikan kepada petani responden.

Tabel 6. Hasil Rekapitulasi Penilaian Masyarakat Terhadap Peran Penyuluh Pertanian

\begin{tabular}{clcc}
\hline Variabel & \multicolumn{1}{c}{ Sub Variabel } & Nilai & Keterangan \\
\hline 1 & $\begin{array}{l}\text { Penyuluh sebagai } \\
\text { pembimbing }\end{array}$ & 741 & $\begin{array}{c}\text { Sangat } \\
\text { Berperan }\end{array}$ \\
& $\begin{array}{l}\text { Petani } \\
\text { Penyuluh sebagai } \\
\text { teknisi lapangan }\end{array}$ & 764 & $\begin{array}{c}\text { Sangar } \\
\text { Berperan } \\
\text { Sangat }\end{array}$ \\
3 & $\begin{array}{l}\text { Penyuluh sebagai } \\
\text { penghubung }\end{array}$ & 716 & $\begin{array}{c}\text { Berperan } \\
\text { Sangat } \\
\text { Penyuluh } \\
\text { pertanian dalam } \\
\text { menginkatkan } \\
\text { hasil tani }\end{array}$ \\
& Jumlah & 706 & $\begin{array}{c}\text { Beran } \\
\text { Berperan }\end{array}$ \\
\hline Sumber data primer setelah diolah, 2019 & & \\
\hline
\end{tabular}

Peran Penyuluh Pertanian sebagai pembimbing di Desa Tellu Limpoe mempunyai hubungan terhadap Peningkatan Produksi Padi Di Kabupaten Soppeng. Berdasarkan hasil analisis dapat diketahui bahwa hubungan peran penyuluh sebagai pembimbing terhadap peningkatan produksi padi pada desa Tellu Limpoe sangat berperan. Untuk mendapatkan gambaran yang lebih jelas 
mengenai peran penyuluh pertanian sebagai pembimbing petani di Desa Tellulimpoe dapat dilihat pada gambar 1 .

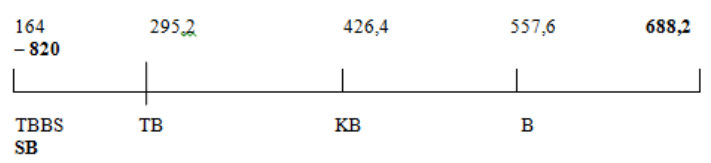

Gambar 1. Peran Penyuluh Pertanian Sebagai Pembimbing Penyuluh Petani

Dari nilai ini dapat di buat kategori sebagai berikut:

Sangat Berperan $(\mathrm{SB})=688,8-820$

Berperan

(B) $=557,6-688,8$

Kurang Berperan $(\mathrm{KB})=426,4-557,6$

Tidak Berperan $\quad(\mathrm{TB})=295,2-426,4$

Tidak Berperan Sama Sekali $($ TBBS $)=164-$ 295,2

Gambar 1 menunjukkan bahwa nilai yang diperoleh pada variable Penyuluh sebagai pembimbing Petani adalah 741, yang berada pada rentang kelas $(688,8-$ 820) artinya peran penyuluh sebagai pembimbing sangat berperan terhadap peningkatan produksi padi di desa Tellu Limpoe hal ini disebabkan karena Penyuluh Pertanian memberikan arahan dan masukan kepada para petani agar dapat meningkatkan produksi padi para petani. Penyuluh membimbing petani dalam mengatasi hambatan ataupun permasalahan yang berasal dari petani misalnya masalah mengenai pembagian pengairan. Penyuluh membimbing petani dalam menyediakan saprodi misalnya Traktor, alat semprot dll. Selain itu penyuluh pertanian juga merupakn sarana kebijaksanaan yang dapat digunakan Pemerintah untuk membimbing para petani umtuk mendorong pembangunan pertanian. Petani mempunyai kebebasan utuk menerima atau menolak saran yang diberikan agen penyuluh pertanian.dengan demikian penyuluhan hanya dapat mencapai sasarannya jika perubahan yang diinginkan sesuai dengan kepentingan petani. (Van Den Ban dan Hawkins, 2013).

Peran Penyuluh Pertanian sebagai Teknisi Lapangan di Desa Tellu Limpoe memiliki hubungan dengan Peningkatan Produksi Padi Di Kabupaten Soppeng. Dengan hasil analisis ini diketahui bahwa hubungan peran penyuluh sebagai pembimbing terhadap peningkatan produksi padi di desa Tellu Limpoe sangat berperan. Untuk mendapatkan gambaran yang lebih jelas mengenai Peran Penyuluh Pertanian sebagai teknisi lapangan di Desa Tellu Limpoe dapat dilihat pada Gambar 2.

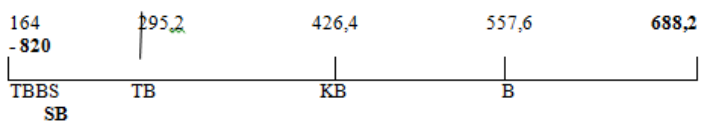

Gambar 2. Peran Penyuluh Pertanian Sebagai Teknisi Lapangan

Dari nilai ini dapat di buat kategori sebagai berikut:

Sangat Berperan $(\mathrm{SB})=688,8-820$

Berperan $\quad$ (B) $=557,6-688,8$ 
Kurang Berperan $(\mathrm{KB})=426,4-557,6$

Tidak Berperan $(\mathrm{TB})=295,2-426,4$

Tidak Berperan Sama Sekali $($ TBBS $)=164-$ 295,2

Gambar 2 menunjukkan bahwa nilai yang diperoleh pada variable Penyuluh sebagai teknisi lapangan adalah 764, yang berada pada rentang kelas $(688$ - 820) artinya peran penyuluh sebagai Teknisi Lapangan sangat berperan terhadap peningkatan produksi padi di desa Tellu Limpoe hal ini disebabkan karena penyuluh pertanian selain memberikan arahan untuk para petani, penyuluh juga ikut serta dalam membantu petani untuk meningkatkan produksi padi para petani. Penyuluh berperan dalam memberikan pelayanan yang baik seperti melayani pengaduan atas masalah petani seperti banyaknya serangan hama atau hal lainnya dengan cepat dan konsisten. Penyuluh berperan dalam memperaktikkan apa yang telah di demonstrasikan mengenai programprogram penyuluhan.

Peran Penyuluh Pertanian sebagai Penghubung antara lembaga penelitian dengan petani di Desa Tellu Limpoe memiliki hubungan dengan Peningkatan Produksi Padi Di Kabupaten Soppeng. Berdasarkan hasil analisis dapat diketahui bahwa hubungan peran penyuluh sebagai Penghubung antara lembaga penelitian dengan petani terhadap peningkatan produksi padi pada desa Tellu Limpoe sangat berperan.Untuk mendapatkan gambaran yang lebih jelas mengenai Peran Penyuluh Pertanian sebagai sebagai Penghubung antara lembaga penelitian dengan petani di Desa Tellu Limpoe dapat dilihat pada Gambar 3.

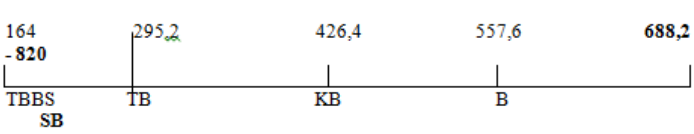

Gambar 3. Peran Penyuluh Pertanian sebagai Sebagai Penghubung Antara Lembaga Penelitian

Dari nilai ini dapat di buat kategori sebagai berikut:

Sangat Berperan $(\mathrm{SB})=688,8-820$

Berperan $\quad(B)=557,6-688,8$

Kurang Berperan $(\mathrm{KB})=426,4-557,6$

Tidak Berperan $(\mathrm{TB})=295,2-426,4$

Tidak Berperan Sama Sekali $($ TBBS $)=164-$ 295,2

Gambar 3 menunjukkan bahwa nilai yang diperoleh pada variable Penyuluh sebagai penghubung adalah 716, yang berada pada rentang kelas (688 - 820) artinya peran penyuluh sebagai penghubung antara lembaga penelitian sangat berperan terhadap peningkatan produksi padi di desa Tellu Limpoe hal ini disebabkan karena penyuluh pertanian menjembatangi antara petani dan 
lembaga-lembaga pertanian yang ada di Kabupaten Soppeng.

Peran Penyuluh Pertanian dalam meningkatkan Hasil Petani Padi di Desa Tellu Limpoe mempunyai hubungan terhadap Peningkatan Produksi Padi Di Kabupaten Soppeng. Berdasarkan hasil analisis dapat diketahui bahwa hubungan peran penyuluh sebagai Pertanian dalam meningkatkan Hasil Petani Padi terhadap peningkatan produksi padi pada desa Tellu Limpoe sangat berperan. Untuk mendapatkan gambaran yang lebih jelas mengenai Peran Penyuluh Pertanian dalam meningkatkan Hasil Petani Padi di Desa Tellu Limpoe dapat dilihat pada Gambar 4.

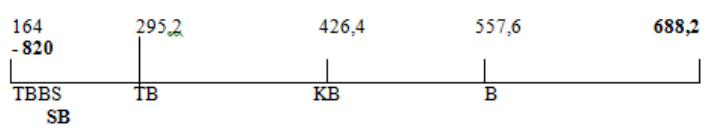

Gambar 4. Peran Penyuluh Pertanian dalam Meningkatkan Hasil Petani Padi

Dari nilai ini dapat di buat kategori sebagai berikut:

Sangat Berperan

$(\mathrm{SB})=688,8-820$

Berperan

(B) $=557,6-688,8$

Kurang Berperan $(\mathrm{KB})=426,4-557,6$

Tidak Berperan $\quad(\mathrm{TB})=295,2-426,4$

Tidak Berperan Sama Sekali $($ TBBS $)=164-$ 295,2

Gambar 4 menunjukkan bahwa nilai yang diperoleh pada variable Peran Penyuluh Pertanian dalam meningkatkan Hasil Petani Padi adalah 706, yang berada pada rentang kelas $(688-820)$ artinya peran penyuluh sebagai Pertanian dalam meningkatkan Hasil Petani Padi sangat berperan terhadap peningkatan produksi padi di desa Tellu Limpoe hal ini disebabkan karena penyuluh pertanian selalu memberikan arahan pada kelompok tani dan juga menyediakan sarana produksi pertanian kepada para petani. Perogram penyuluhan bertujuan untuk melakukan perubahan prilaku petani untuk meraih kesuksesan, khususnya untuk memecahkan masalah petani, sehingga bisa lebih sejahtera dalam meningkatkan produksinya. (Van Den, 2013).

Tabel 6 menunjukkan Hasil Rekapitulasi Penilaian Masyarakat Terhadap Peran Penyuluh Pertanian sebanyak 2.927 untuk hasil keseluruahn dengan rentang nilai $(2.756-3.280)$ termasuk dalam kategori Sangat Berperan. Untuk indikator 1 peran Penyuyluh sebagai pembimbing sangat berperan karena Penyuluh Pertanian memberikan arahan dan masukan kepada para petani agar dapat meningkatkan produksi padi para petani. Penyuluh membimbing petani dalam mengatasi hambatan ataupun permasalahan yang berasal dari petani misalnya masalah mengenai pembagian pengairan. Penyuluh membimbing petani dalam menyediakan saprodi misalnya 
Traktor, alat semprot dll. Untuk indikator 2 peran penyuluh sebagai teknisi lapangan sangat berperan karena penyuluh pertanian selain memberikan arahan untuk para petani, penyuluh juga ikut serta dalam membantu petani untuk meningkatkan produksi padi para petani. Penyuluh berperan dalam memberikan pelayanan yang baik seperti melayani pengaduan atas masalah petani seperti banyaknya serangan hama atau hal lainnya dengan cepat dan konsisten. Penyuluh berperan dalam memperaktikkan apa yang telah di demonstrasikan mengenai programprogram penyuluhan. Untuk indikator 3 peran peyuluh sebagai penghubung antara lembaga penelitian dengan petani sangat berperan karena penyuluh pertanian menjembatangi antara petani dan lembaga-lembaga pertanian yang ada di Kabupaten Soppeng. Dan indikator 4 peran penyuluh pertanian dalam meningkatkan hasil petani padi sangat berperan karena penyuluh pertanian selalu memberikan arahan pada kelompok tani dan juga menyediakan sarana produksi pertanian kepada para petani.

\section{KESIMPULAN DAN SARAN}

Hasil penelitian dan pembahasan dapat ditarik kesimpulan bahwa pandangan masyarakat terhadap peran penyuluh pertanian terhadap peningkatan wawasan/ pengetahuan dalam meningkatkan produksi petani padi adalah indikator 1) Peran penyuluh sebagai pembimbing petani, 2) Peran penyuluh sebagai teknisi lapangan, 3) Peran penyuluh sebagai penghubung antara lembaga dengan petani, dan 4) Peran penyuluh pertanian dalam meningkatkan hasil petani padi, semuanya sangat berperan dalam meningkatkan wawasan/ pengetahuan dalam meningkatkan produsi petani padi dan juga peran penyuluh sangat penting bagi petani di Desa Tellulimpoe untuk dapat meningkatka produksi padi.

\section{DAFTAR PUSTAKA}

Adi Yanto,Peran penyuluh pertanian lapa ngan (PPL) terhadap Usahatani padi organic (Studi Kasus di kecamatan Ngombol Kabupaten Purweorejo. Skripsi. Prodi Agribisnis.Universitas Muhammadi yah Purworejo. 2017.

Lusiana, Dkk. Peranan Penyuluh Pertanian Dalam Meningkatkan Pendapatan Usahatani Padi Sawah Didesa Oloboju Kecamatan Sigi Biromaru Kabupaten Sigi. Jurnal Pogram Studi Agribisnis. Universitas Tadulako. 2018.

Ni Komang Maya Gitasmara, Dkk. Peranan Penyuluh Pertanian Lapangan Dalam Pembuatan Pupuk Organik Padat (Kasus Pada Kelompok Ternak Putra Kertha Santhi, Lingkungan Kebon, Kelurahan Baler Bale, Kecematan 
Negara, Kabupaten Jembrana). Jurnal Agribisnis Dan Agrowisata. Prodi Agribisnis Universitas Udayana. 2017.

Putra, Wicaksono. 2012. Menentukan Jumlah Sampel dengan Rumus Slovin.

http://analisis statistika.blogsopt.co m/2012/09/menentukan-jumlahsampel-dengan-rumus.html?m-1. Diakses pada tanggal 06 April 2019. Sekar Inten M, Dkk. Peranan Penyuluh Pertanian Dalam Peningkatan Pendapatan Petani Komoditas Padi Di Kecamatan Tanjungselor Kabupaten Bulungan Kalimantan Utara. Jurnal Prodi Agribisnis, Fakultas Pertanian, Universitas Borneo, Tarakan. 2017.

Sugiono. 2013. Metode Penelitian Bisnis. Bandung: Penerbit Alfabeta.

Sundari,Peranpenyuluh pertanian terhada p peningkatan produksi usaha tani di Kabupaten Pontianak. Jurnal. Prodi Agribisnis. Universitas Tanjungpura Pontianak. 2015.

Van Den Ban dan Hawkins, 2013. Penyuluhan Pertanian. Kanisius. Yogyakarta. 